Vol.46, n. 4 : pp. 553-561, December 2003 ISSN 1516-8913 Printed in Brazil

\title{
Bacteriocinogenic Effect of Lactobacillus sakei 2a on Microbiological Quality of Fermented Sardinella Brasiliensis
}

\author{
Milton L. P. Espírito Santo ${ }^{1 *}$, Luiz H. Beirão ${ }^{1}$, Ernani S. Sant'Anna ${ }^{1}$, Eliana Bressa \\ Dalcin $^{1}$ and Bernadette G. M. Franco ${ }^{2}$ \\ ${ }^{1}$ Departamento de Ciência e Tecnologia de Alimentos; Centro de Ciências Agrárias; Universidade Federal de \\ Santa Catarina; 88034-001; Florianópolis - SC - Brazil. ${ }^{2}$ Departamento de Alimentos e Nutrição Experimental; \\ Faculdade de Farmácia; Universidade de São Paulo; São Paulo - SP - Brazil
}

\begin{abstract}
Lactobacillus sakei $2 a$ is a bacteriocin producer strain and, in this work, it's effects as a starter culture in the fermentation process of sardine (Sardinella brasiliensis) fillets were observed at different concentrations of NaCl (2, 4 and 6\%) and glucose (2 and 4\%), to determine it's ability to produce organic acids and consequent pH reduction. Experiments were carried out independently, with only one parameter (NaCl or glucose) varying at a time. After 21 days of fermentation the deteriorative bacteria concentration reached $9.7 \quad \log _{10}$ CFU. $g^{-1}$ corresponding to $6 \% \mathrm{NaCl}$ and $4 \%$ glucose. Little differences were observed in lactic acid production when 2 and $4 \%$ glucose were added, since total acidity was 1.32 and $1.34 \%$ respectively, the experiments with $6 \% \mathrm{NaCl}$ presented the best results. Initial pH of sardine fillets was 6 and after 21 days pH values were 3.8, 3.9 and 4 for the experiments with 2, 4 and $6 \% \mathrm{NaCl}$. This may have been due to the inhibitory properties of $\mathrm{NaCl}$ over the deteriorative bacteria. After 21 days of the fermentation process lactic acid bacteria concentrations were 14.5 Log $_{10}$ $C F U . g^{-1}$. The ratio protein nitrogen and total soluble nitrogen was typical of a cured fish.
\end{abstract}

Key words: Sardinella brasiliensis, Lactobacillus sakei 2a, fermented fish

\section{INTRODUCTION}

Despite the recent progress in food biotechnology with the introduction of modern technologies and safety concepts (e.g. HACCP), the problem of food safety and security remains to be solved. On the other hand, consumer trends lead to a loss of intrinsic preservation and to a potential loss of protection from processing, since consumers prefer more stable and safer products with a longer shelf life and without chemical preservatives, as well as mild and light products with a low acid, sugar, salt or fat content. The manufacturers strategies to increase the safety of fish and fish products consist of developing new technologies to reduce the number of microorganisms in fish, and new products minimally processed which could represent new hazards for health because of the pathogen growth (Hugas, 1998; Aymerich et al., 1998). LAB have been playing an important role in food fermented causing flavor and texture changes together with a preservative effect resulting in increase in the shelf life of the transformed product (Paludan-Müller et al., 2002;Reid, 1999; Zhang and Holley, 1999;). The present study examined the effect of Lactobacillus sakei $2 \mathrm{a}$ on the fermentation of sardine fillets. Fish-NaCl-glucose system was used to evaluate the factors that favor a rapid lactic fermentation. 


\section{MATERIALS AND METHODS}

Fermentation of fish: Fresh sardine were deheaded, degutted, filleted and stored at $30^{\circ} \mathrm{C}$ until processed. The fillet was then divided into $300 \mathrm{~g}$ portions in sterile flasks, and various amounts of $\mathrm{NaCl}$ and glucose (2-4\%) were added. The influence of $\mathrm{NaCl}$ and glucose were determined, using Lactobacillus sakei $2 \mathrm{a}$ as starter culture. Two independent experiments were performed in duplicate, in which only 1 parameter $(\mathrm{NaCl}$ or glucose) varied. Concentrations tested (expressed on total weight of sardine and water mixture) were $0,2,4$ and $6 \% \mathrm{NaCl} ; 0,2$ and $4 \%$ glucose. The system was inoculated with single strains at a level of $10^{8} \mathrm{CFU} \cdot \mathrm{g}^{-1}$ and fermented at $23-24^{0} \mathrm{C}$ for 21 days. The speed and efficiency of the lactic fermentation was monitored by the rate of $\mathrm{pH}$ decrease and the balance between lactic acid bacteria (LAB) counts and total spoiler counts on plate count agar (PCA). The slower grower LAB on PCA is easily excluded from the total spoiler count. The competition between LAB and spoilers is expressed as the log ratio between the counts on MRS and PCA media (Zhang and Holley, 1999; Gonzáles-Fernandez et al., 1997).

Bacterial strain: Lactobacillus sakei 2a, isolated from "lingüiça" (a typical Brazilian meat product), were kindly provided by Faculdade de Ciências Farmacêuticas, Universidade de São Paulo (De Martinis and Franco, 1997; GonzálesFernandez et al., 1997).

Morphophysiological and biochemical
characteristics of strain: The strain (Latobacillus sakei 2a) were characterized by Gram-reaction, morphology (phase-contrast microscopy), growth at $8,15,45{ }^{\circ} \mathrm{C}$ and $\mathrm{pH} 3.9$, halophilism at $6.5,7$ and $10 \% \mathrm{NaCl}$, motility, catalase test $\left(20 \% \mathrm{H}_{2} \mathrm{O}_{2}\right)$, Voges-Proskauer reaction (MR-VP medium), methyl red test, formation of $\mathrm{H}_{2} \mathrm{~S}$, gas from glucose, lysine decarboxylase, indole test, gelatin liquefaction, bacteriocins production and carbohydrates fermentation (acid production). Glucose fermentation and gas production were tested in MRS broth with $1 \%$ glucose and Durham tubes. The detection of bacteriocins produced was examined using the well - diffusion assay (Lewus et al., 1991). A modification of the well - diffusion assay method was employed as follow. Cell-free supernatant from MRS broth culture of putative bacteriocin producer were collected by centrifugation at $9.77 \mathrm{x} \mathrm{g}$ for $10 \mathrm{~min}$. The supernatant were neutralized to $\mathrm{pH} 7$ with $1 \mathrm{~N}$ $\mathrm{NaOH}$ and sterilized by filtration (membrane GV Millipore - $0.22-\mu \mathrm{m}$ ). Pour plate were prepared from BHI containing $1 \%$ agar seeded with $10^{6}$ UFC. $\mathrm{mL}^{-1}$ of Listeria monocytogenes Scott A. Wells cut into the pour plates with sterile straws were filled with $40 \mu \mathrm{L}$ of the culture supernatant. The plate was incubated anaerobically overnight at $30^{\circ} \mathrm{C}$. Inhibition was detected by a zone of clearing round the supernatant well (Lewus and Montville, 1991).

Growth of Lactobacillus sakei 2a: Viable counts of Lactobacillus sakei 2a were determined by plating (aliquots of $1 \mathrm{~mL}$ ) on MRS agar (Oxoid CM 361).

Culture was grown in MRS for $48 \mathrm{~h}$ at $30{ }^{\circ} \mathrm{C}$ to reach the stationary phase. The broth was centrifuged and the cell pellet was resuspended in diluent containing $1 \%(\mathrm{w} / \mathrm{v})$ peptone in sterile deionized water. Serial dilutions were made and for each dilution, the optical density was measured at $\mathrm{OD}_{600} \mathrm{~nm}_{\mathrm{m}}$ using an MC 0141/visible spectrophotometer and the cell suspension was surface plated on MRS agar for enumeration. A linear relationship between the cell concentrations and optical densities was obtained around $10^{8}-10^{9}$ CFU. $\mathrm{mL}^{-1}$ levels (Lewus and Montville, 1991; De Man et al., 1960).

Microbiological analyses of sardine fillets: Samples of sardine fillets $(10 \mathrm{~g})$ were aseptically removed and homogenized for $3 \mathrm{~min}$ in peptone water $(90 \mathrm{~mL})$. The homogenate was serially diluted and used for enumeration of microorganisms. Total bacteria counts were determined on Plate Count Agar (PCA, Oxoid CM 463) after incubation at $30^{\circ} \mathrm{C}$ for $48 \mathrm{~h}$ for enumeration of Enterococcus, Staphylococcus positive coagulase were enumerated on BairdParker Medium (Oxoid CM 275) and coliforms were enumerated on Violet Red Bile Agar (Oxoid CM 107). Presence of Salmonella was assessed following the procedure described in APHA (1992); after enrichment in peptone water overnight and in Rappaport-Vassiliadis broth (Oxoid CM 669) at $37^{\circ} \mathrm{C}$ for $24 \mathrm{~h}$, samples were streaked on Brilliant Green Agar (Oxoid CM 263) and plates were incubated at $37^{\circ} \mathrm{C}$ for $24 \mathrm{~h}$. 
Chemical analysis: The proximate composition (moisture, protein, fat and ash) of the raw sardines sample used in the present experiment were determined following the standard methods described by AOAC (1995).

Total titratable acidity (TTA): Using the same homogenate prepared for the determination of $\mathrm{pH}$, the TTA was measure by titration with $0.1 \mathrm{~N}$ sodium hydroxide to a final $\mathrm{pH}$ of 8 . The $\% \mathrm{w} / \mathrm{w}$ lactic acid in the sample was calculated by multiplying the volume of alkali $(\mathrm{mL})$ by the factor 0.09 (AOAC, 1995). This assumes that all the acid present in the sample is lactic acid.

Total soluble nitrogen and free amino nitrogen: The samples were analyzed for total soluble nitrogen (TSN), protein (total $\mathrm{N} x$ 6.25) and free amino nitrogen, FAN ( $\alpha$-amino nitrogen) content using methods AOAC (1995).

Physical analysis: $10 \mathrm{~g}$ of each sample was then taken and blended with $90 \mathrm{~mL}$ deionised water. The $\mathrm{pH}$ of the homogenized samples was measured with a pH meter (Corning pH meter 240, Corning, New York, USA). Samples were analyzed on a wet weight (as is) basis (MA, 1982).

Data analysis: The significance of effects of different process parameters and combinations of conditions in simulation assays were determined by 1- way analysis of variance.

\section{RESULTS AND DISCUSSION}

\section{Raw material}

The approximate composition of the raw sardines sample used in the experiment was: protein (19\%), fat $(3.1 \%)$, moisture $(73.4 \%)$ and ash $(1.9 \%)$ (Table 1).

Table 1 - Proximate composition of sardine fillets

\begin{tabular}{lccccc}
\hline & $\mathrm{R}_{1}$ & $\mathrm{R}_{2}$ & $\mathrm{R}_{3}$ & $\mathrm{X}$ & $\mathrm{Dp}$ \\
\cline { 2 - 6 } Moisture & 72,9 & 73,5 & 73,7 & 73,4 & \pm 0.39 \\
Fat & 2.0 & 3.0 & 4.2 & 3.1 & \pm 0.89 \\
Protein & 19,7 & 19,6 & 17,7 & 19,0 & $\pm 0,88$ \\
Ash & 2,0 & 1,9 & 1,9 & 1,9 & $\pm 0,01$ \\
\hline
\end{tabular}

$\mathrm{R}_{1,2,3}$ : samples.

$\mathrm{X}$ : means, Dp: standard deviation.
The chemistry composition of fish (Sardinella sp.) is complex; traditionally had a range of fat values from $2 \%$ (spring) to $8.6 \%$ (autumn (and moisture values from 66 to $84 \%$ (result were similar to the marine fish) (Badolato et al., 1994). The microbial analysis of raw is shown in Table 2.

\section{Morphophysiological and biochemical characteristics of $L$. sakei 2 a}

The strain was identified as cocci Gram-positive, rods in short chains (1-7 cell units), nonsporing and no motile. The colonies showed: white to cream in color, circular shape, smooth, brilliant, convex, creamy consistency and diameter between 0,5 and $1 \mathrm{~mm}$. L. sakei $2 \mathrm{a}$ is aerotolerant and grow at 7 and $10 \% \mathrm{NaCl}$, at $\mathrm{pH} 3.9$ and temperature at $8{ }^{0} \mathrm{C}$ and $15{ }^{\circ} \mathrm{C}$ but not at $45{ }^{\circ} \mathrm{C}$ (Table 3 ). The biochemical characteristics of the L. sakei $2 \mathrm{a}$ are presented in Table 4.

Table 2 - Microbiological characteristics of raw material

\begin{tabular}{|c|c|c|c|}
\hline & $\mathbf{R}_{1}$ & $\mathbf{R}_{2}$ & $\mathbf{R}_{\mathbf{3}}$ \\
\hline $\begin{array}{l}\text { Aerobic mesophilic } \\
\text { bacteria }\left(\mathrm{CFU} . \mathrm{g}^{-1}\right)\end{array}$ & $3.5 \times 10^{2}$ & $1.1 \times 10^{4}$ & $4.4 \times 10^{3}$ \\
\hline $\begin{array}{l}\text { Coliforms } \\
\left(\mathrm{MPN} \cdot \mathrm{g}^{-1}\right)\end{array}$ & $<3$ & $<3$ & $<3$ \\
\hline $\begin{array}{l}\text { Fecal coliforms } \\
\left(\mathrm{MPN} \cdot \mathrm{g}^{-1}\right)\end{array}$ & $<3$ & $<3$ & $<3$ \\
\hline $\begin{array}{l}\text { Staphylococcus } \\
\text { positive coagulase } \\
\left.\text { (CFU. } \mathrm{g}^{-1}\right)\end{array}$ & $<10^{2}$ & $<10^{2}$ & $<10^{2}$ \\
\hline $\begin{array}{l}\text { Enterococcus } \\
\left(\text { CFU. }{ }^{-1}\right)\end{array}$ & $3.5 \times 10^{2}$ & $3.5 \times 10^{2}$ & $3.5 \times 10^{2}$ \\
\hline Salmonella sp. & Absence & Absence & Absence \\
\hline
\end{tabular}

$\mathrm{R}_{1,2,3}$ : means of three samples.

Table 3 - Physiological characteristics of the Lactobacillus sakei $2 \mathrm{a}$

\begin{tabular}{cccccccc}
\hline $\mathrm{pH}$ & \multicolumn{2}{c}{$\begin{array}{c}\text { Halofilismo } \\
(\%\end{array}$} & \multicolumn{2}{c}{$\begin{array}{c}\text { Growth } \\
\left({ }^{\circ} \mathrm{C}\right)\end{array}$} & $\begin{array}{c}\text { Gelatin } \\
\text { liquefaction }\end{array}$ \\
\hline 3.9 & 6.5 & 7 & 10 & 8 & 15 & 45 & \\
+ & + & + & $\mathrm{W}$ & + & + & - & - \\
\hline
\end{tabular}

Symbols: (+) positive reaction, (-) negative reaction and (w) slight reaction. 
Table 4 - Biochemical characteristics of the Lactobacillus sakei $2 \mathrm{a}$

\begin{tabular}{lc}
\hline Production & Reactions \\
\hline Catalase & - \\
Voges-Proskauer & + \\
Gas from glucose & - \\
$\mathrm{H}_{2} \mathrm{~S}$ & - \\
Indole & - \\
Lysine decarboxylase & + \\
Methyl red & + \\
Bacteriocins & + \\
\hline Fermentation & \\
\hline Lactose & - \\
Sucrose & + \\
Glucose & + \\
Rhamnose & - \\
Xylose & - \\
Arabinose & + \\
Raffinose & - \\
Galactose & + \\
Maltose & - \\
Trehalose & - \\
Sorbitol & - \\
\hline
\end{tabular}

The microbiological quality of the raw material was good. Numbers of aerobic mesophilic bacteria (PCA) in the raw material ranged from $3.5 \times 10^{2}$ to $1.1 \times 10^{4}$ CFU.g ${ }^{-1}$. Enterococcus counts were below $\log _{10} 4 \times 10^{2}$ CFU.g ${ }^{-1}$. Staphylococcus positive coagulase counts were $<10^{2}$ CFU. $\mathrm{g}^{-1}$. Salmonella were not detected.

\section{Production of bacteriocin in broth}

The Fig. 1 shown the growth of the L.sakei 2a in MRS broth at $30^{\circ} \mathrm{C}$.

Culture of L.sakei 2a was grown to 19 hours. The bacteriocins production only began after 4 hours of incubation (Fig. 2) when the bacterial amount was $9.0 \times 10^{6}$ CFU. $\mathrm{mL}^{-1}$. In function of the inhibition zone observed and using L. monocytogenes Scott A as sensitive microorganism, the bacteriocins production obtained its maximum value after 7 hours. After this time there was not more bacteriocins production.

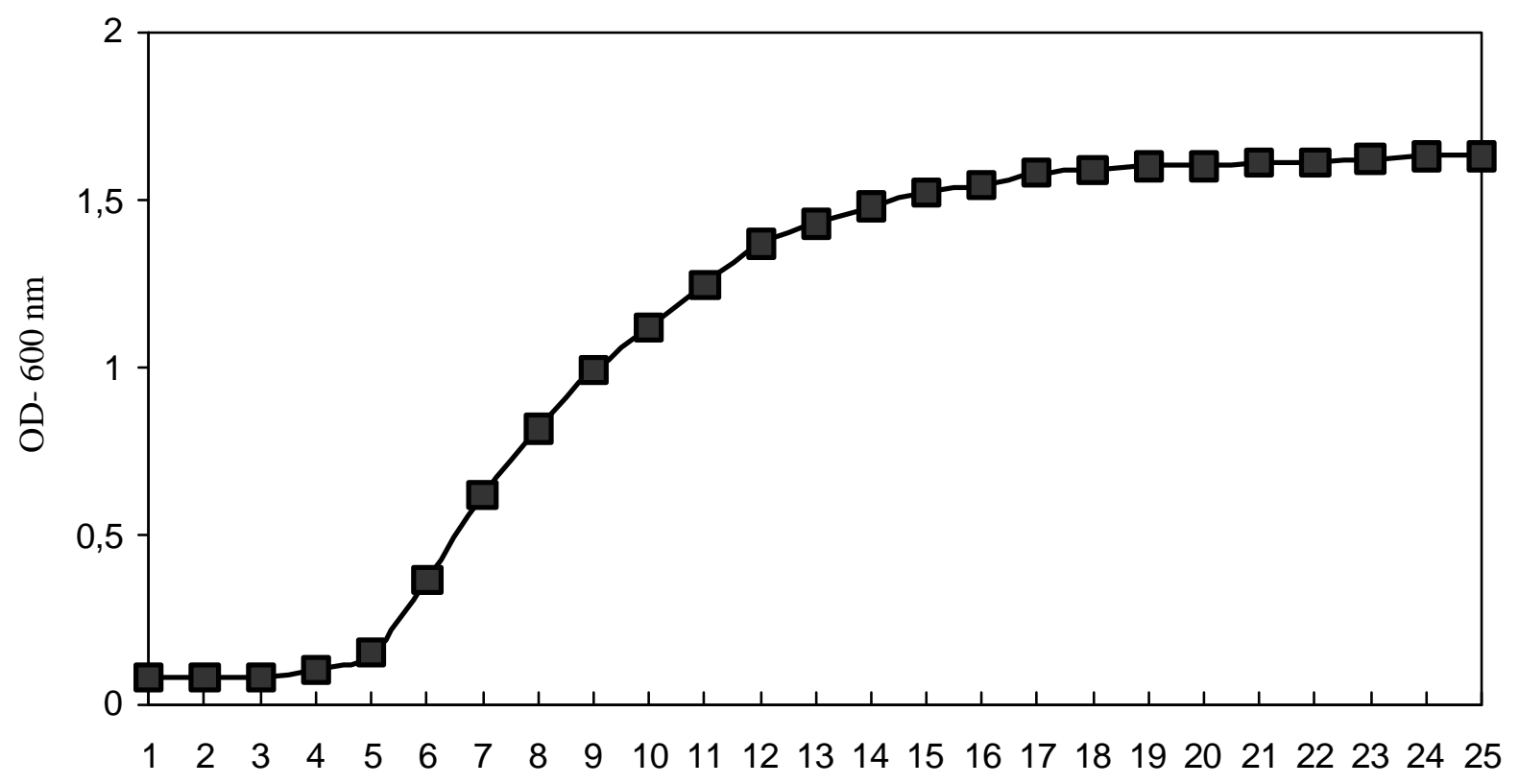

Figure 1 - Growth of L sakei 2a in MRS incubated at $30^{\circ} \mathrm{C}$ for 24 hours. 


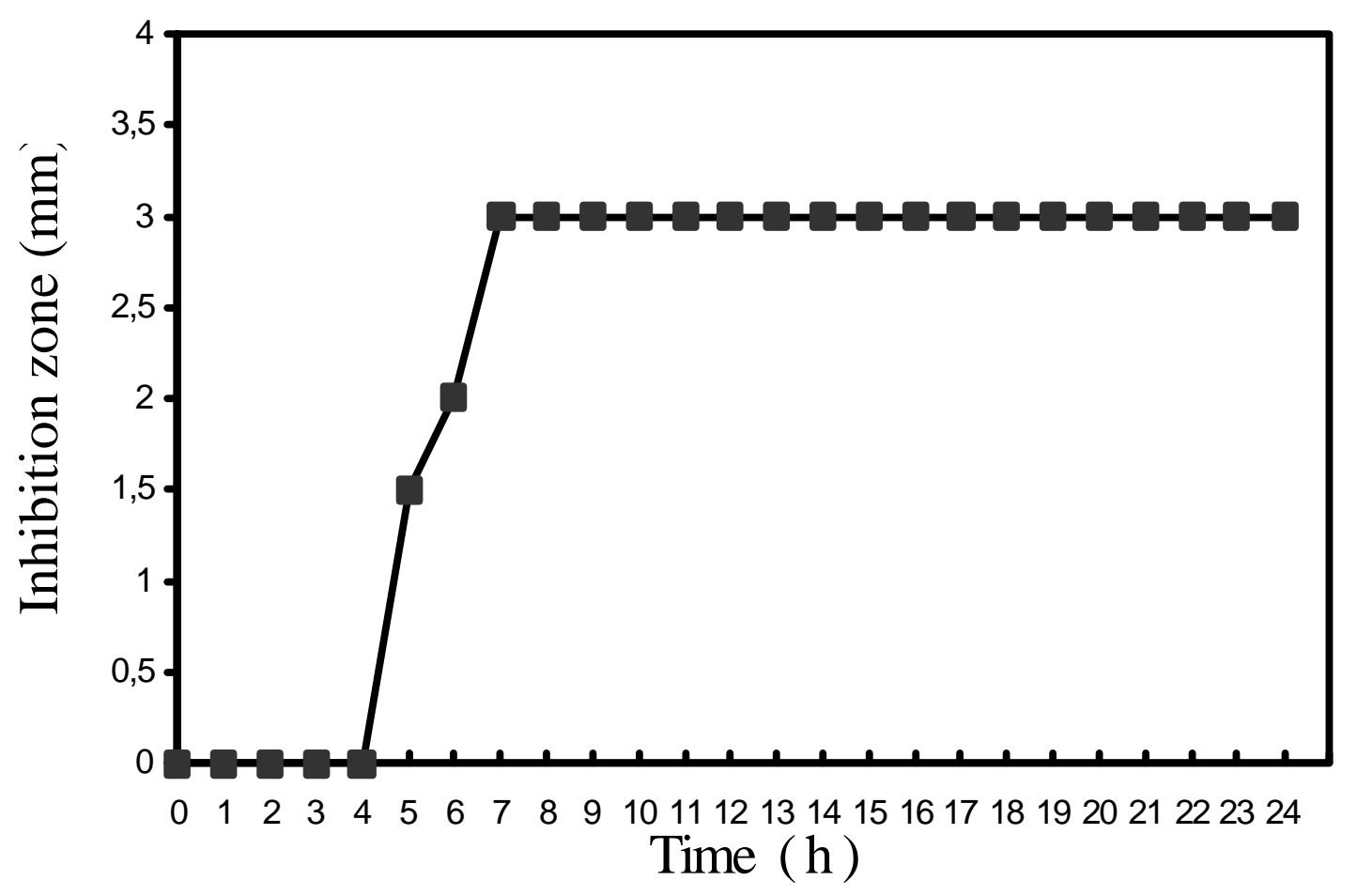

Figure 2 - Detection of bacteriocins produced by L. sakei 2a in MRS, incubated at $30{ }^{0} \mathrm{C}$ for 24 hours.

\section{Optimization of fermentation parameters using the model system}

The effect of $\mathrm{NaCl}$ on the $\mathrm{pH}$ of sardine without starter and glucose was presented in Fig.3. The $\mathrm{pH}$ values increased in all samples. The addition of $6.0 \% \mathrm{w} / \mathrm{w} \mathrm{NaCl}$ caused the $\mathrm{pH}$ to remain above 6,6 throughout the 5 day incubation period.

Table 5 - Effect of the $\mathrm{NaCl}$ and glucose on the acidity $(\%)$ during sardine fermentation

\begin{tabular}{ccccccc}
\hline \multirow{2}{*}{$\begin{array}{c}\text { Time } \\
\text { (days) }\end{array}$} & \multicolumn{3}{c}{ 2\% Glucose } & \multicolumn{3}{c}{ 4\% Glucose } \\
\cline { 2 - 7 } NaCl & \multicolumn{3}{c}{ NaCl } \\
\cline { 2 - 7 } & $2 \%$ & $4 \%$ & $6 \%$ & $2 \%$ & $4 \%$ & $6 \%$ \\
\hline 0 & 0.48 & 0.48 & 0.48 & 0.48 & 0.48 & 0.48 \\
7 & 1.21 & 1.12 & 0.74 & 1.77 & 1.42 & 0.79 \\
14 & 1.73 & 1.60 & 1.22 & 2.55 & 2.23 & 1.32 \\
21 & 2.55 & 2.23 & 1.32 & 2.76 & 2.64 & 1.34 \\
\hline
\end{tabular}

The addition of carbohydrate is necessary to promote a satisfactory fermentation since fish flesh is very low in free carbohydrate. The speed and efficiency of the lactic fermentation was monitored by the rate of $\mathrm{pH}$ decrease and the balance between lactic acid bacterial (LAB counts and total spoiler (bacterial) counts on plate count agar (PCA). Results of the chemical analysis showed that acidity increases as fermentation progresses, as shown in Table 5.

Table 6 - Effect of the $\mathrm{NaCl}$ and glucose on the $\mathrm{pH}$ during sardine fermentation

\begin{tabular}{ccccccc}
\hline \multirow{2}{*}{$\begin{array}{c}\text { Time } \\
\text { (days) }\end{array}$} & \multicolumn{3}{c}{ 2\% Glucose } & \multicolumn{3}{c}{ 4\% Glucose } \\
\cline { 2 - 7 } & \multicolumn{3}{c}{ NaCl } & \multicolumn{3}{c}{ NaCl } \\
\cline { 2 - 7 } & $2 \%$ & $4 \%$ & $6 \%$ & $2 \%$ & $4 \%$ & $6 \%$ \\
\hline 0 & 6.0 & 6.0 & 6.0 & 6.0 & 6.0 & 6.0 \\
7 & 4.1 & 4.2 & 4.3 & 4.0 & 4.1 & 4.2 \\
14 & 4.1 & 4.2 & 4.3 & 4.0 & 4.0 & 4.1 \\
21 & 4.0 & 4.1 & 4.2 & 3.8 & 3.9 & 4.0 \\
\hline
\end{tabular}

The $\mathrm{pH}$ values decreased in all samples (Table 6). Final $\mathrm{pH}$ and $\%$ titrable acidity obtained after 21 days of fermentation were $\mathrm{pH} 4$ and $2.55 \%$ (2\% $\mathrm{NaCl}$ and $2 \%$ glucose). The $\mathrm{pH}$ decrease with glucose content $(2 \% \mathrm{w} / \mathrm{w})$, whereas increasing the $\mathrm{NaCl}$ concentration from $2-6 \%$ slows the fermentation rate. Using $2 \% \mathrm{w} / \mathrm{w} \mathrm{NaCl}$ with $2 \%$ $\mathrm{w} / \mathrm{w}$ glucose resulted in a acidity increase to approximately $1.21 \%$ after 7 days and $2.55 \%$ after 
21 days. Incorporating 6\% w/w $\mathrm{NaCl}$ resulted in an acidity increase to $0.74 \%$ after 7 days and $1.32 \%$ after 21 days. However, the reproducibility of fermentation rates between different batches of whiting was quite variable in the all-important first 2-day period. One explanation is that this reflects the differing degrees of freshness of the commercially obtained fish and its effect on the LAB: spoiler's competition.
Table 7 - Effect of the $\mathrm{NaCl}$ and glucose on the growth of lactic acid bacteria $\left(\log _{10}\right.$ CFU.g $\left.{ }^{-1}\right)$ during sardine fermentation

\begin{tabular}{ccccccc}
\hline \multirow{2}{*}{$\begin{array}{c}\text { Time } \\
\text { (days) }\end{array}$} & \multicolumn{3}{c}{ 2\% Glucose } & \multicolumn{3}{c}{ 4\% Glucose } \\
\cline { 2 - 7 } & $2 \%$ & $4 \%$ & $6 \%$ & $2 \%$ & $4 \%$ & $6 \%$ \\
\hline 0 & 5.2 & 5.2 & 5.2 & 5.2 & 5.2 & 5.2 \\
7 & 1.6 & 9.9 & 8.9 & 11.6 & 11.0 & 9.8 \\
14 & 1.6 & 1.2 & 1.9 & 14.6 & 13.6 & 12.9 \\
21 & 1.2 & 1.0 & 1.9 & 15.3 & 15.0 & 14.5 \\
\hline
\end{tabular}
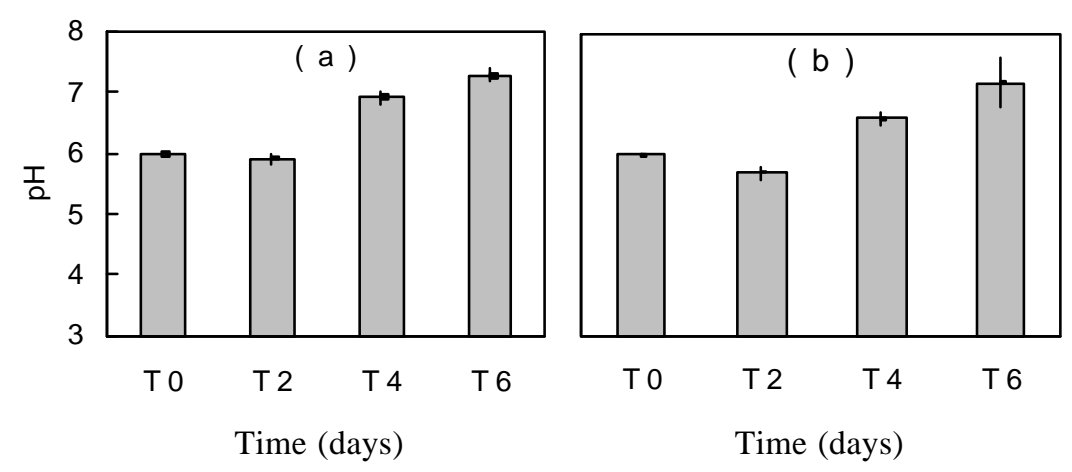

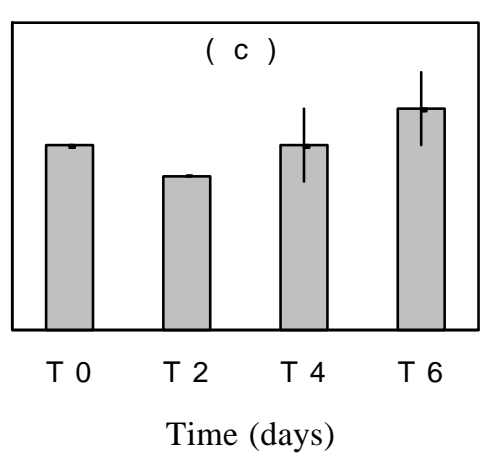

Figure 3 - Changes in the $\mathrm{pH}$ during sardine fermentation (without starter and glucose) with 2 w/w $\% \mathrm{NaCl}$ (a), 4 w/w\% $\mathrm{NaCl}$ (b) and 6 w/w $\% \mathrm{NaCl}$ (c).

Results showed that the full potential of acid production was obtained with a glucose level of $4 \%$. It was observed that $\mathrm{NaCl}$ has a negative effect on both bacterial growth and $\mathrm{pH}$ drop, by reducing the $A_{w}$ and creating conditions unfavorable for LAB. The effect was observed even at the lowest concentration (2\%). However, $\mathrm{NaCl}$ presents other desirable properties such as flavor enhancement and preservative effect. Figure 4 shows the trend in the total plate count (TPC). A sharp increase was observed on the first day, after which increase was more gradual up to the fifth day. The sharp increase could be due to the presence of non-acid producing colonies that gradually disappeared as the environment becomes more acidic. The sharp increase could be due to the presence of non-acid producing colonies that gradually disappeared as the environment becomes more acidic. The results of the determination of the non-acid formers (NAF) and acid formers (AF), given in Fig.4 and 5, show that $\mathrm{AF}$ predominated almost throughout the seven-day fermentation period while NAF were present only at the early stages of the fermentation. The viability of non-acid formers existed only for a short period of time since the environment would be inhibitory to them as the fermentation progressed due to the production of lactic acid.

The inoculation with starter culture significantly inhibited the growth of spoilage microorganisms, maintaining the samples in relatively good microbiological quality throughout the study. In the inoculated samples, LAB counts increased at 5.0 $\log _{10}$ CFU.g ${ }^{-1}$ during the 21td day (Fig. 5). The evidence for autolysis in this experiment was provided by changes in the ratio of free amino nitrogen to total soluble nitrogen (Fig. 6).

This ratio increase slightly during the fermentation period, indicating the occurrence of autólise. Samples produced with $\mathrm{NaCl}$ at $6 \%$ showed less autolysis than samples with $2 \%$. 

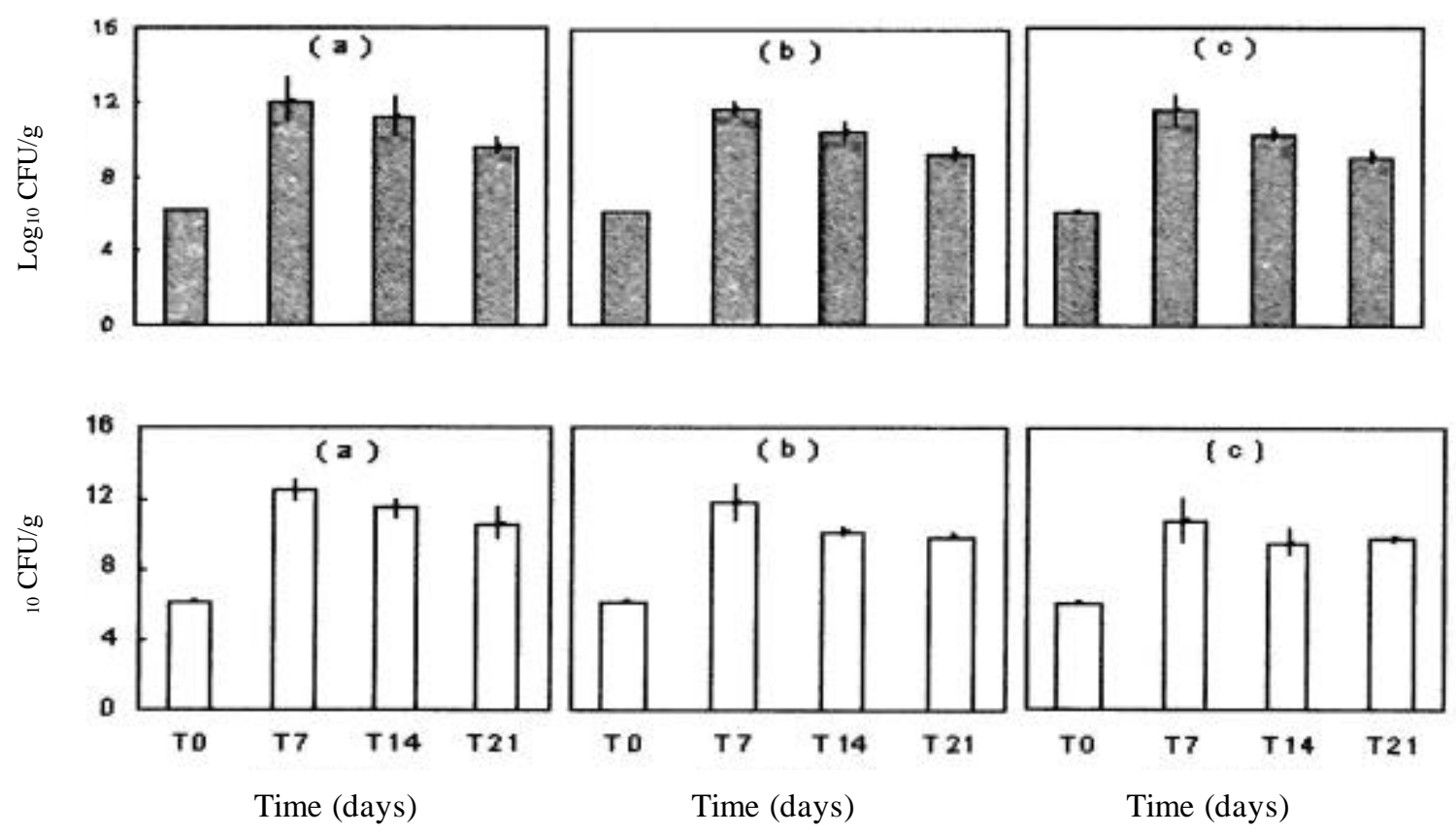

Figure 4 - Changes in the total plate count on nutrient agar during sardine fermentation. Samples were formulated with combinations of various proportions of $\mathrm{NaCl}$; (a) $2 \%$, (b) $4 \%$, (c) $6 \%$ and glucose; $2 \% \square, 4 \% \square$.
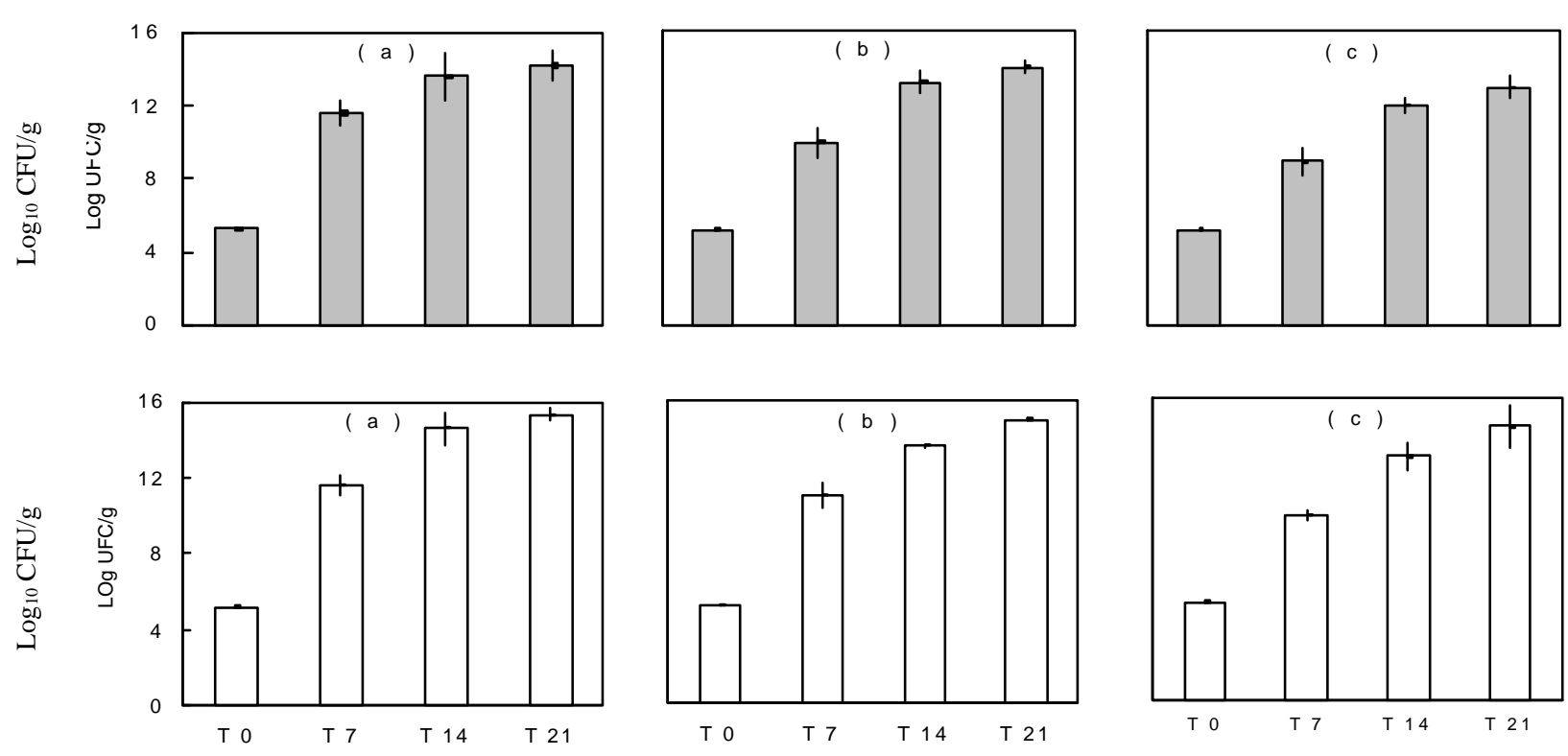

Time (days)

Time (days)

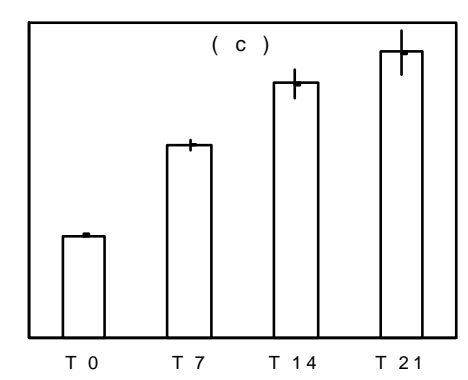

Time (days)

Figure 5 - Changes in the total plate count on MRS agar during sardine fermentation. Samples were formulated with combinations of various proportions of $\mathrm{NaCl}$; (a) $2 \%$, (b) $4 \%$, (c) $6 \%$ and glucose; $2 \%, 4 \% \square$. 


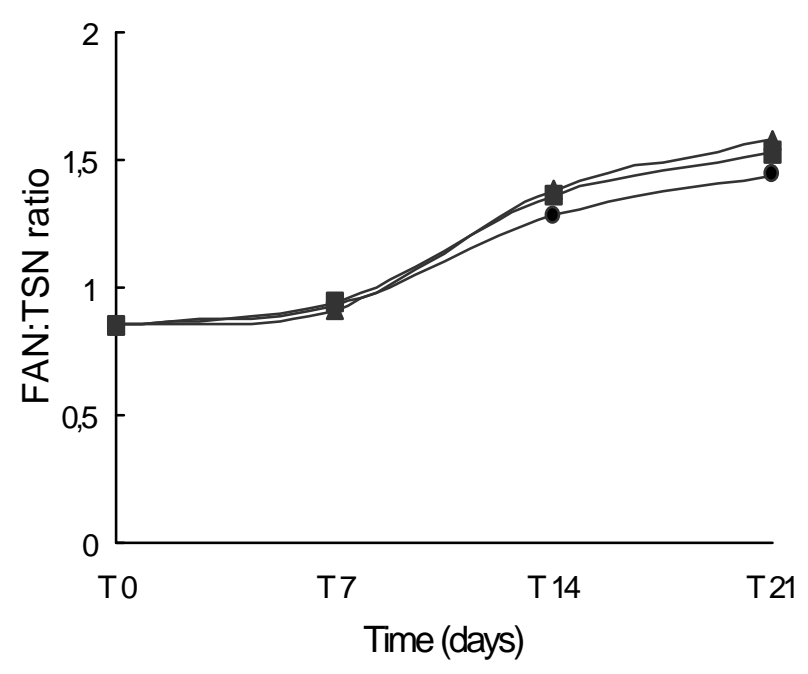

Symbols: $\bullet 2 \%$ glucose and $2 \% \mathrm{NaCl},-2 \%$ glucose and $4 \% \mathrm{NaCl}$,

- $2 \%$ Glucose and $6 \% \mathrm{NaCl}$

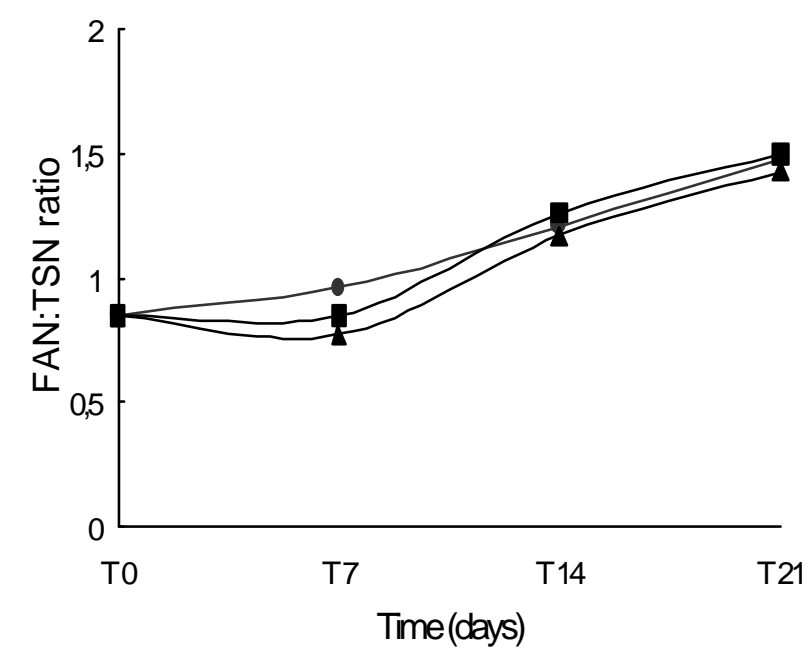

Symbols: $\bullet 4 \%$ glucose and $2 \% \mathrm{NaCl},-4 \%$ glucose and $4 \% \mathrm{NaCl}$,

- $4 \%$ Glucose and $6 \% \mathrm{NaCl}$

Figure 6 - Effect of glucose (2 and 4\%) and $\mathrm{NaCl}(2,4$ and 6\%) on sardine autolysis (Free amino nitrogen/ total soluble nitrogen).

Addition of the higher amount of $\mathrm{NaCl}$ could have slowed down the breakdown of the fish meat by autolysis or microbial activities (Ijong and Ohta, 1996).Control of natural fermentation by addition of amine-negative starter cultures has been suggested to prevent amine formation (fish fermented) (Roi-Sagués and Eerola, 1997). One of the most widely studied starter cultures is
Pediococcus cerevisae. Inoculation with aminenegative $P$. cerevisae starter cultures reduces the amount of biogenic amines formed. The research trends towards food preservation focus on mild, physical preservation techniques and the use of natural antimicrobial compounds because of consumer attitude in the last years towards chemical, unnatural preservatives and the demand 
for "natural" and fresher foods. (Hugas, 1998; Zhang and Holley, 1999). The production of competitive and bacteriocinogenic lactic acid bacteria may well provide an additional hurdle to improve fish preservation by natural means.

\section{RESUMO}

Lactobacillus sakei é comprovadamente uma cepa produtora de bacteriocinas e, neste trabalho procurou-se observar seus efeitos como cultivo iniciador, na fermentação de filés de sardinhaverdadeira (Sardinella brasiliensis) em diferentes concentrações de $\mathrm{NaCl}(2,4$ e $6 \%)$ e glicose (2 e $4 \%$ ), observando-se sua capacidade para produzir ácidos orgânicos e conseqüente redução do $\mathrm{pH}$ e microrganismos deterioradores. Os tratamentos foram desenvolvidos de forma independente, variando apenas um dos parâmetros operacionais $(\mathrm{NaCl}$ ou glicose). Ao término de 21 dias de fermentação, a concentração de microrganismos deterioradores atingiu $9,7 \quad \log _{10} \quad$ UFC. ${ }^{-1}$, correspondente a $6 \%$ de $\mathrm{NaCl}$ e $4 \%$ de glicose. Poucas diferenças foram observadas na produção de ácido lático quando se adicionou 2 e $4 \%$ de glicose; a acidez foi 1,32 e $1,34 \%$, respectivamente, para os experimentos com $6 \%$ $\mathrm{NaCl}$, os quais apresentaram os melhores resultados. $\mathrm{O} \mathrm{pH}$ inicial dos filés de sardinha foi seis e, ao término de 21 dias, 3,8, 3,9 e 4, equivalente aos experimentos com 2,4 e $6 \% \mathrm{NaCl}$. Este comportamento pode ser atribuído ao poder inibidor do $\mathrm{NaCl}$ sobre a microbiota deterioradora. Ao término de 21 dias de fermentação a concentração de bactérias ácido láticas foi 14,5 $\log _{10}$ UFC.g ${ }^{-1}$.

\section{REFERENCES}

American Public Health Association (1992), Compendium of methods for the microbiological examination of foods. 3. ed. Washington.

Association of Official Analytical Chemists (1995), Official Methods of Analysis, $16^{\text {th }}$ ed. W. Horwitz (ed.), Washington.

Aymerich, M. T.; Hugas, M.; Monfort, J. M. (1998), Review: Bacteriocinogenic lactic acid bacteria associated with meat products. Food Sci. Technol. Int., 3 : (4), 141-158.
Badolato, E. S. G.; Carvalho, J. B.; Amaral Mello, M. R. P.; Tavares, M.; Campos, N. C.; Aued-Pimentel, S. and Morais, C. (1994), Composição centesimal de ácidos graxos e valor calórico de cinco espécies de peixes marinhos nas diferentes estações do ano. Rev. Inst. Adolfo Lutz, 54, 27-35.

De Man, J. C.; Rogosa, M. and Sharp, M. E. (1960), A medium for the cultivation of lactobacilli. J. Appl. Bacteriol., 23, 130-135.

De Martinis, E. C. P. and Franco, B. D. G. M. (1997), Inhibition of foodborne by bacteriocin-producing Leuconostoc sp. and Lactobacillus sake isolated from "lingüiça frescal”. Rev. Microbiol., 28, 284-287.

Gonzáles-Fernandez, C.; Santos, E. M.; Jaime, I. and Rovira, J. (1997), Utilización de cultivos iniciadores en la elaboración de chorizo y su influencia en las propriedades sensoriales. Food Sci.Tech. Int., 3 : (1), 31-42.

Hugas, M. (1998), Bacteriocinogenic lactic acid bacteria for the biopreservation of meat and meat products. Meat Sci., 49 : (1), SI39-SI50.

Ijong, F. G. and Ohta, Y. (1996), Physicochemical and microbiological changes associated with Bakasang processing - A traditional Indonesian fermented fish sauce. J. Sci. Food Agric., 71 : (1), 69-74.

Lewus, C. B.; Kaiser, A. and Montville, T. J. (1991), Inhibition of food-borne bacterial pathogens by bacteriocins from lactic acid bacteria isolated from meat. Appl. Environ. Microbiol., 57, 1683-1688.

Lewus, C. B. and Montville, T. J. (1991), Detection of bacteriocins produced by lactic acid bacteria. J. Microbiol. Met., 13, 145-150.

Ministério da Agricultura (1982), Laboratório nacional de referência animal. Métodos microbiológicos para análises alimentos.

Paludan-Müller, C.; Madsen, M.; Sophanodora, P.; Gram, L.; Müller, P. L. (2002), Fermentation and microflora of plaa-som, a Thai fermented fish product prepared with different salt concentrations, 73, 61-70.

Reid, G. (1999), The Scientific basis for probiotic strains of Lactobacillus. Appl. Env. Microbiol., 65, 3763-3766.

Roig-Sagués, A. and Eerola, S. (1997), Biogenic amines in meat inoculated with Lactobacillus sake starter strains and an amine-positive lactic acid bacterium. Food Res.Technol., 205 : (3), 227-231.

Zhang, G. and Holley, R. A. (1999), Development and PFGE monitoring of dominance among spoilage lactic acid bacteria from cured meats. Food Microbiol., 16, 633-644. 